\title{
Anti-angiopoietin Monoclonal Antibody AMG 780
}

National Cancer Institute

\section{Source}

National Cancer Institute. Anti-angiopoietin Monoclonal Antibody AMG 780. NCI

Thesaurus. Code C116627.

An immunog lobulin (Ig) G2 monoclonal antibody targeting the proangiogenic cytokines angiopoietin 1 (Ang 1) and 2 (Ang2), with potential anti-angiog enic and antineoplastic activities. Upon administration, anti-ang iopoietin monoclonal antibody AMG 780 binds to Ang 1 and Ang 2. This prevents the binding of the angiopoietin lig ands to their receptor Tie2 (TEK), an endothelial cell-specific receptor tyrosine kinase. This prevents Tie2mediated signaling and results in an inhibition of T ie2-expressing, tumor-stimulated endothelial cell proliferation, which prevents angiogenesis and inhibits tumor cell proliferation. 